Migration Studies - Review of Polish Diaspora nr 4 (174)/2019, http://www.ejournals.eu/Studia-Migracyjne/ DOI: 10.4467/25444972SMPP.19.042.11356

\title{
Role polskich kobiet w kształtowaniu i wspieraniu tożsamości dzieci pochodzenia polskiego w społecznych szkołach polonijnych we Francji
}

\author{
ANETA KRZYWORZEKA-JELINOWSKA ${ }^{1}$ \\ Uniwersytet Warszawski
}

\begin{abstract}
Historia migracji Polek i Polaków do Francji jest długa, bogata i zróżnicowana pod względem płci migrujących osób, wykształcenia, struktury wieku oraz powodów emigracji. Ostatnia fala emigracji, która opuściła kraj w okresie przystąpienia Polski do Unii Europejskiej i otwarcia francuskiego rynku pracy dla Polaków, charakteryzuje się wyraźną samoorganizacją w sferze praktyk edukacyjnych dla dzieci. Oddolna mobilizacja edukacyjna jest zdecydowanie zdeterminowana przez płeć, a jej siłę i determinację unaoczniają liczne szkoły społeczne powstałe z indywidualnych i kolektywnych inicjatyw. W artykule przedstawię wstępne wyniki moich badań pochodzące z wywiadów pogłębionych z liderkami i nauczycielkami tamtejszego środowiska polonijnego oraz uzupełnię je wnioskami z obserwacji uczestniczącej.
\end{abstract}

Słowa kluczowe: diaspora polska, szkolnictwo polonijne, kobiety, liderki, tożsamość narodowa

\section{The Role of Polish Women in Shaping and Supporting the Identity of Children of Polish Origin in Polish Saturday Schools in France}

The history of migration of Polish women and men to France is long, rich and diverse in terms of gender, education level, age structure and purpose of emigration. The last wave of emigration, which dates to around Poland's accession to the European Union and the opening of the French labor market for Poles, is characterized by a clear self-organization in the sphere of educational practices for children. The grassroots of educational mobilization is definitely determined by gender and numerous supplementary schools created from individual and collective initiatives illustrate

\footnotetext{
1 Kontakt: aneta.krzyworzeka@uw.edu.pl
} 
its strength and determination. In the article I present the preliminary results of my research resulting from in-depth interviews with leaders and teachers of the Polish diaspora in France. I conclude with the analysis of questionnaires and participant observation.

Key words: Polish diaspora, diaspora schools, Polish women, leaders, national identity

\section{Wstęp}

Masowe migracje Polaków po 2005 roku stały się wyzwaniem dla państwa polskiego biorąc pod uwagę ich skalę oraz skutki. Tracąc kapitał kulturowy, społeczny oraz ekonomiczny, państwo przestaje być konkurencyjne oraz innowacyjne (Kaczmarczyk, Okólski 2005). Zagadnienie emigracji polskich obywateli oraz związane z nim zagrożenia były już wielokrotnie podejmowane przez specjalistów i świat nauki, według których:

najnowsza fala emigracji z Polski winna być zatem obiektywnie rozpoznana, opracowana i wyjaśniona nie tylko ze względu na skalę odpływu, ale przede wszystkim - na wielowymiarowe i dalekosiężne skutki dla społeczeństwa polskiego (Slany, Solga 2014: 6).

Cztery lata wcześniej, „Komisja do Badań Diaspory Polskiej” Polskiej Akademii Umiejętności uchwaliła, iz:

Szczególną uwagę pragniemy zwrócić na konieczność całkowicie nowego zorganizowania systemu kształcenia dzieci nowych emigrantów w zakresie języka polskiego i wiedzy o Polsce, tak, aby nie utraciły one więzi z kulturą i krajem rodziców. Obecny system jest bowiem zupełnie nieprzystosowany do skali problemu, wobec którego stanęło nasze społeczeństwo. Zrealizowanie tego zadania będzie wymagało wielkiego wysiłku, począwszy od wykształcenia znacznej liczby wykwalifikowanych nauczycieli, a skończywszy na działaniach dyplomatycznych, aby zapewnić językowi polskiemu odpowiednią pozycję w państwach, gdzie przebywa znaczna liczba naszych rodaków (PAU 2010).

Według członków Polskiej Akademii Umiejętności migracja ponad 2 mln Polaków (ostatnie dane szacunkowe 2 mln 540 tys., GUS 2018), głównie młodych ludzi i tych z wyższym wykształceniem, to nie tylko odpływ ich kapitału społecznego z Polski, ale także utrata go wśród dzieci, które urodzą się już poza Polską. Ich identyfikacja z polską tożsamością narodową będzie miała decydujący wpływ na dalsze kontakty rodzin z krajem pochodzenia. Ostatnie odpływy Polaków są nieporównywalne z poprzednimi falami migracji, a stojące przed nimi wyzwania związane ze wielokulturowością, multietnicznością nie ułatwią procesu socjalizacji ich dzieciom. Chociaż stoją przed nimi zadania, o istnieniu których być może nie myśleli wcześniej, to do nich będzie należał wybór strategii edukacyjnej ich dzieci. To od ich decyzji oraz możliwości zaangażowania się w ten proces zależy, czy dzieci staną się dwujęzyczne i dwukulturowe. Poprzez migracje międzynarodowe rodziny stają się pionierami międzykulturowości 


\section{SM̂PP}

i samodzielnych sposobów radzenia sobie z wielokulturowością w życiu codziennym, których podstawą są refleksyjne negocjacje (Slany, Solga 2014: 31).

Uważam, że najmłodsze pokolenie polskiego pochodzenia podczas procesu kształtowania się tożsamości jest poddawane podwójnej socjalizacji, która jest skomplikowana i pełna napięć. To napięcie, często ambiwalencja, może trwać długo, a w konsekwencji pozostać nierozstrzygnięte. Może też nastąpić reintegracja różnych tożsamości, a jednostka może wykorzystać różnorodność do tworzenia własnej wyjątkowej tożsamości, której spójna narracja będzie łączyła elementy wyniesione z różnych sytuacji (Giddens 2002). Zadanie wydaje się dużo trudniejsze, jeśli okaże się, że w przyszłości część rodzin będzie chciała powrócić do Polski. Sytuacja rodziców i dzieci stanie się diametralnie różna. Dla rodziców będzie to powrót do w miarę czytelnych kodów kulturowych, a dla dzieci będzie to już migracja wraz ze wszystkim wyzwaniami, jakie ona niesie za sobą.

O ile dla rodziców powrót do kraju może być upragnionym zwieńczeniem kilkuletniej pracy za granicą, o tyle dla dzieci (szczególnie urodzonych w kraju emigracji) doświadczenie to będzie wiązało się z wyrwaniem ze znanego i bezpiecznego środowiska i koniecznością adaptacji do nowej sytuacji. Dzieci posiadające doświadczenia migracyjne (szczególnie te związane z (re)emigracją) określa się mianem „ukrytych migrantów”, ze względu na fakt, iż w wielu wypadkach nie są rozpoznawane przez decydentów jako grupa wymagająca wsparcia (Grzymała-Moszczyńska 2015: 34).

Celem artykułu jest zwrócenie uwagi na problematykę społecznych szkół polonijnych powstałych po wejściu Polski do UE, a głównie po otwarciu dla Polaków europejskich rynków pracy. Polska posiada długą i mocną tradycję w tworzeniu niezależnych struktur, których celem jest przekazywanie języka polskiego, tradycji i postawy patriotycznej wobec kraju rodziców, a losy polonijnego szkolnictwa unaoczniają niezwykłą determinację Polaków tej kwestii. Przykładem może być okres II wojny światowej, gdzie jej zasięg geograficzny obejmował takie kraje jak: Rumunia, Węgry, Szwecja, Jugosławia, Szwajcaria, ZSRR, W. Brytania, Włochy, Indie, Persja, Afryka Wschodnia (tj. Kenia, Uganda i Tanzania) i Południowa, Algier, Rodezja, Bliski Wschód, Liban, Meksyk, Nowa Zelandia (Dzwonkowski 1981: 1). Mimo że specyfika tych placówek zależy konkretnie od poszczególnych krajów, to jednak zawiera wspólne elementy dla wszystkich. Centralnym problemem prezentowanych danych jest określenie i analiza zakresu ról podejmowanych przez Polki (liderki, dyrektorki, nauczycielki) w sferze edukacyjnej w wyżej wspomnianych placówkach. Za pomocą przyjętej typologii chciałabym wyróżnić i podkreślić wyzwania, z jakimi borykają się współcześnie przede wszystkim polskie emigrantki w procesie przekazywania więzi ze swoim krajem urodzenia.

Artykuł powstał w oparciu o wyniki szerszych badań przeprowadzanych w ramach rozprawy doktorskiej zatytułowanej „Polonijne szkoły społeczne we Francji. Między dziedzictwem Wielkiej Emigracji a wyzwaniami współczesnego świata. Studium przypadku". Na podstawie dwóch placówek edukacyjnych (region paryski i południe 
Francji), utworzonych już po akcesji Polski do UE, przygotowuję analizę organizacji systemu edukacji polonijnej oraz jego roli w kształtowaniu się tożsamości narodowej dzieci urodzonych we Francji (w rodzinach jedno oraz dwukulturowych i więcej). Wstępne wyniki badań pozwalają na określenie dynamiki obserwowanych zjawisk i poczynienie pierwszych wniosków.

Wybrane przeze mnie techniki badawcze należą do grupy metod mieszanych, zarówno jakościowych, jak i ilościowych. W ramach grupy badań ilościowych zostały przeprowadzone ankiety wśród członków społeczności polonijnych zgromadzonych wokół szkół będących przedmiotem badań. Celem przeprowadzenia ankiet było zebranie danych, aby wstępnie określić charakterystykę badanej grupy. W grupie dokumentów zastanych zostały poddane analizie ustawy określające relacje między państwem polskim a jego diasporami i programy wspomagające funkcjonowanie środowisk polonijnych. W ramach obserwacji uczestniczącej w wyżej wymienionych placówkach, oprócz obserwacji życia szkoły, relacji uczniowskich, nauczycielskich, między rodzicami i nauczycielami, przeanalizowałam inne źródła zastane, takie jak podręczniki (do języka polskiego oraz historii), dokumentację szkół, gazetki szkolne, kroniki. Kolejny etap badań składał się ze spotkań i wywiadów (pogłębionych, częściowo strukturyzowanych z elementami wywiadu biograficznego) z twórcami szkół, liderkami społeczności polonijnych, nauczycielami i rodzicami. Badania obejmują lata 2016-2018 i zostały przeprowadzone w placówce znajdującej się w regionie paryskim (ok. 300 dzieci) oraz placówce mieszczącej się na południowym zachodzie Francji (ok. 30 dzieci). Obie placówki zostały wybrane intencjonalnie i skontrastowane w celu uzyskania pełniejszych danych. Pierwsza placówka znajduje się w najatrakcyjniejszym regionie Francji ze względu na możliwości zawodowe dla imigrantów (także polskich), stąd ich liczba jest tam największa. Druga, odległa od stolicy, jest bardzo interesująca ze względu na długą tradycję emigrowania tam Polaków zajmujących się górnictwem. Choć dzisiaj ten sektor nie oferuje już zatrudnienia, wciąż przybywa tam nowa, młoda Polonia.

Na podstawie wstępnych wyników badań pochodzących z wywiadów, obserwacji i ankiet, wyróżniłam kilka typów ról definiujących polskie kobiety na gruncie zadań związanych z funkcjonowaniem najmłodszych polonijnych szkół społecznych we Francji. Ze względu na zakres i charakter ich działań są to następujące typy: menadżerka, przewodniczka, obywatelka świata.

\section{Polonia we Francji}

Diaspora polska we Francji ma długą i różnorodną historię, w której można wyróżnić co najmniej cztery fale migracyjne. Pierwszą z nich tworzyli Polacy, którzy opuścili tereny polskie będące pod zaborami po upadku powstania listopadowego. Okres ten określa się czasem Wielkiej Emigracji we Francji. Drugą falę reprezentowali Polacy, 


\section{SM̂PP}

którzy przyjechali do Francji na mocy umowy bilateralnej zawartej między Francją i Polską, a obejmuje ona okres 1918-1945. Celem tej akcji było zasilenie pracownikami polskiego pochodzenia takich sektorów jak: rolnictwo, górnictwo oraz przemysł, po utracie przez Francję swojej ludności w czasie I wojny światowej. Niektórzy z nich, zachęceni propagandą komunistyczną, powrócili do Polski po roku 1945, aby z niej niezwłocznie powtórnie wyjechać (Ponty 2008, Nisiobęcka 2018). Trzecią określamy emigrantów powojennych, pokłosie roku 1968 i lat 80. XX w. Ten okres charakteryzował się tym, że z punktu widzenia powodów wyjazdu z Polski, emigracja polska była zarówno polityczna, jak i ekonomiczna. Do emigracji politycznej zaliczamy działaczy "Solidarności”, którzy przekształcali się w emigrantów zarobkowych. Za czwartą autorka będzie uznawać ostatnią falę Polaków, którzy zdecydowali się wyjechać do Francji, z powodu otwarcia rynku pracy w 2008 roku (tzw. migranci poakcesyjni), choć już wcześniej, tj. od momentu wejścia do Unii Europejskiej, ich zatrudnienie stało się tam częstsze (INSEE 2013). Począwszy od pierwszej fali emigracyjnej, jak i w kolejnych, powstawały instytucje polonijne powoływane przez Wielką Emigrację i emigrację powojenną (po II wojnie światowej), w tym Biblioteka Polska w Paryżu, a także środowisko czasopisma "Kultura” (Heruday-Kiełczewska 2012).

Diaspora polska we Francji uważana była za jedną z liczniejszych w świecie. Szacuje się, iż liczy ona ok. 800 tys. osób. Dane te są wynikiem analizy opartej m.in. na rejestrach urodzeń dzieci polskich we Francji, rejestrach paszportowych czy obserwacji rosnącego zapotrzebowania Polaków na zapewnienie polskiej edukacji (MSZ 2015). Liczba ta obejmuje Polaków i osoby polskiego pochodzenia przybyłe do Francji w różnych okresach historycznych, jak również ich potomków, a więc osoby pochodzenia polskiego mające obywatelstwo polskie i francuskie lub tylko francuskie.

Ostatnie lata przyniosły kolejny napływ Polaków do Francji tzw. migrantów poakcesyjnych, choć nieporównywalny z exodusem Polaków do Wielkiej Brytanii. Według danych GUS (szacunkowych) liczba nowych emigrantów polskich we Francji podwoiła się z 30 tys. (2004) do 64 tys. (GUS 2018). Według francuskiego instytutu statystycznego przedstawiciele najmłodszej fali imigrantów polskich do Francji w latach 2004-2012 mieli między 20 a 39 lat. Ponad połowę (55\%) stanowiły kobiety. W zdecydowanej większości to mężczyźni deklarowali zatrudnienie we Francji jako powód przyjazdu do tego kraju (80\%), zaś kobiety częściej osiedlały się z powodów rodzinnych. Biorąc pod uwagę kategorię wykształcenia polskich imigrantów we Francji, Polacy plasują się tuż za najlepiej wykształconymi imigrantami we Francji (USA, Rosja) i 41\% z nich ma wyższe wykształcenie, a 29\% średnie (INSEE 2013). Przyrost polskiej emigracji stał się przyczyną powstania nowych społecznych szkół polonijnych i dużego zaangażowania rodziców w edukację dzieci. W związku z tym, że Francja nie zbiera danych uwzględniających zatrudnienie $w$ danym sektorze uwzględniające narodowość, mogę jedynie zasygnalizować, iż najczęściej Polacy pracują w sektorach takich jak: budownictwo, transport, usługi lub jako pracownicy sezonowi. 


\section{Szkolnictwo polonijne we Francji}

Początki są nierozerwalnie związane z inicjatywami oddolnymi, samoorganizacją Polaków przebywających za granicą oraz ze wsparciem ze strony polskiego Kościoła katolickiego. Placówki edukacyjne miały służyć przede wszystkim najmłodszym Polakom, urodzonym poza krajem. To tam mieli odebrać edukację narodową w duchu patriotyzmu opartą na wartościach katolickich, gdzie taki zestaw był uważany za cechy konstytutywne polskiej tożsamości narodowej (Pugacewicz 2017).

Szkolnictwo polonijne we Francji zostało zapoczątkowane przez wydarzenia związane z upadkiem powstania listopadowego, a następnie ucieczki biorących w nim udział żołnierzy i aktywistów. W tamtym okresie Francja przyjmowała uchodźców politycznych z wielu stron Europy oraz jednocześnie kształtowała swoje ustawodawstwo regulujące pobyt takich osób, przygotowując podwaliny polityki migracyjnej. Francuskie społeczeństwo obawiało się przyjazdu polskich mężczyzn, z którymi sobie nie radzono, przede wszystkim z powodu bariery językowej, różnic kulturowych oraz ich temperamentu (Diaz 2014). Z tego powodu francuska administracja państwowa była zmuszona do podjęcia szczególnych kroków, na przykład niełączenia grup polskich i hiszpańskich żołnierzy w jednym ośrodku. Polscy żołnierze i ich przełożeni wspierani byli przez pewien czas finansowo przez państwo francuskie. Opuszczając specjalnie przygotowane dla nich ośrodki, takie jak w Châteauroux i w Bourges (Diaz 2014: 126), rozpoczynali nowy etap życia, zakładali rodziny i pojawiały się dzieci narodzone już ze związków polsko-francuskich.

Wielka Emigracja, w obawie o utratę polskiej tożsamości narodowej u dzieci (chłopców) z tych związków, postanowiła stworzyć organ umożliwiający naukę przedmiotów w języku polskim. Dzięki temu sieć szkół polonijnych zapoczątkowana została przez pierwszą polską szkołę Batignolles w roku 1842, z inicjatywy ówczesnej emigracji oraz generała Józefa Dwernickiego (Pugacewicz 2017). W latach pięćdziesiątych XIX wieku polska emigracyjna szkoła, została włączona w uniwersytecką strukturę paryskiej Sorbony i w pełni dostosowała się do miejscowych wymogów organizacyjno-programowych (Pugacewicz 2017: 12). W ramach programu nauczano języka francuskiego i polskiego młodszych, a najstarszych wysyłano już do miejscowego liceum.

Nie można pominąć także aspektu nauczania języka polskiego. Warunkiem przyjęcia do szkoły była znajomość języka polskiego. Nie wzięto pod uwagę faktu, iż dzieci urodzone ze związków głównie polsko-francuskich posługiwały się niepoprawną polszczyzną, bądź w ogóle nią nie władały. Już wtedy próbowano samodzielnie przygotowywać i testować nowatorskie programy, które miałyby za cel skorygowanie tego stanu rzeczy. Tworzono własne programy nauczania gramatyki czy też prowadzono wykłady dwujęzyczne, czyli w ramach systemu podwójnie wykładanych lekcji, w oryginale - po francusku, a następnie tłumaczonych przez domowych nauczycieli na język narodowy. Ostatecznie system ten został wyparty w połowie lat 50. XX w., 


\section{SM̂PP}

kiedy uświadomiono sobie, że tak naprawdę ucząc drugie emigracyjne pokolenie języka ojców, uczy się de facto języka obcego, wyeliminowanie zatem „tłumaczeniowej metody" pozwoliło na o wiele lepsze wykorzystanie czasu (Pugacewicz 2017: 317).

Działalność placówki była finansowana głównie ze środków ofiarowanych przez Wielką Emigrację, Komitet Polsko-Francuski generała Lafayette'a czy Ksawerego Branickiego. Szkoła, zmieniając kilkukrotnie lokalizacje wraz z różną liczbą uczniów, przetrwała do 1922 roku, już przy ulicy Lamandé. Przez kolejne kilkanaście lat funkcjonowała tam bursa dla studentów i młodych naukowców. Następnie w jej miejsce powstało polskie liceum (1939 r.), które po wejściu Niemców do Paryża zostało przeniesione do alpejskiej miejscowości Villard-de-Lans. Zarówno dyrekcja, kadra nauczycielska oraz uczniowie ponieśli ogromne straty, w szczególności po ataku Niemców na tamtejsze rejony, słynące z bardzo silnego ruchu oporu. W wyniku działań militarnych zginęli nauczyciele i uczniowie. Dyrektor profesor Zygmunt Lubicz-Zaleski i jego następca prof. Wacław Godlewski zostali wywiezieni do obozów w Buchenwaldzie i w Mauthausen. Formalnie szkoła działała do 1946 roku.

W 1947 roku, na mocy polsko-francuskiej umowy kulturalnej, powstało w Paryżu Liceum Polskie, które po roku 1956 odnotowało znaczący spadek liczby kandydatów (Dzwonkowski 1983). Utrzymywanie szkoły przestało się opłacać, stąd decyzja w roku 1963 o zamknięciu placówki na kilka lat. Do kraju wywieziono akta szkoły villardowskiej i Liceum Polskiego. Ale już w roku 1969, polscy pracownicy, oddelegowani do Francji i skupieni w Związkach Zawodowych Pracowników Państwowych i Społecznych, zorganizowali nowy punkt nauczania (Pugacewicz 2010). Co więcej, wykorzystali do tego jedno z pomieszczeń pierwszej szkoły z 1842 r. w Batignolles. Było to możliwe, ponieważ trzy budynki pierwszej szkoły zostały przejęte przez państwo, a później przeszły w zarządzanie Polskiej Akademii Nauki. Z początkowo niewielkich rozmiarów placówka, w latach 90. XX w. kształciła już ponad 1000 dzieci rocznie (3 oddziały, podstawówka, gimnazjum, liceum oraz kształcenie na odległość).

Współcześnie poza granicami kraju (także we Francji) działają trzy kategorie szkolnych placówek oświatowych, w których naucza się języka polskiego. Pierwszą grupę stanowią szkoły pozostające w ramach polskiego systemu edukacji, czyli takie, które realizują pełny polski program nauczania oraz szkoły przy polskich placówkach dyplomatycznych. Jedne i drugie są całkowicie finansowane przez Ministerstwo Edukacji Narodowej. Drugą grupę stanowią szkoły należące do systemów edukacji innych państw, we Francji będą do niej należeć tzw. sekcje polskie w ramach szkół francuskich. Dla starszych dzieci były i są dostępne możliwości kontynuowania nauki w sekcjach międzynarodowych francuskich szkół średnich ogólnokształcących, gdzie wprowadzono możliwość częściowego nauczania w języku narodowym. System edukacji francuskiej widział w tym dwa nadrzędne cele. Po pierwsze miało to być ułatwienie uczniom-obcokrajowcom wejścia we francuski system szkolny lub pomoc w ewentualnym powrocie do rodzinnego kraju. Po drugie, zakładał stworzenie dla ich francuskich kolegów oraz uczniów innych narodowości, przychylnego klimatu 
i dobrych warunków do nauki języków obcych we wzajemnej interakcji i na najwyższym poziomie (Pugacewicz 2010). Trzecią kategorię tworzą szkoły, które działają w ramach systemu prawnego danego kraju, lecz poza jego systemem edukacji. Do niej należy cała grupa sobotnich szkół polonijnych.

\section{Współczesne szkolnictwo polonijne}

Akcesja Polski do Unii Europejskiej i napływ kolejnych emigrantów z Polski ponownie uruchomiły mechanizm oddolnych inicjatyw obywatelskich, które przypominały zrywy dotyczące reanimacji szkoły przy ulicy Lamandé (kolejna siedziba szkoły batignolskiej) czy szkół powstających dla dzieci górników w na północy Francji. Według Iwony Pugacewicz (2010: 321):

najlepiej i najstabilniej szkolnictwo społeczne rozwija się tam, gdzie jest duża liczba polskiej emigracji oraz nie ma zorganizowanych odgórnie struktur umożliwiających polską/ polonijną edukację (południowa Francja), lub też w tych miejscach, gdzie struktury te nie są w stanie zaspokoić lawinowo rosnących potrzeb polskiego środowiska (okręg paryski).

Szkoły przy ambasadach oraz przykonsularne prowadzą kształcenie na poziomie szkoły podstawowej, gimnazjum i liceum ogólnokształcącego. Realizują podstawę programową kształcenia ogólnego oraz uzupełniający plan nauczania szkoły kraju osiedlenia. W skład tej podstawy wchodzą: język polski, historia Polski, geografia Polski, wychowanie obywatelskie i matematyka. Zajęcia zazwyczaj odbywają się w soboty w godzinach od 9.00 do 15.30 oraz w środowe popołudnia, korzystając z faktu, iż wtedy nie odbywają się zajęcia w szkołach francuskich. Do tych placówek przyjmowane są dzieci obywateli polskich czasowo przebywających za granicą i które uczęszczają do szkół lokalnego systemu edukacyjnego. Dzieci, które nie mają polskiego obywatelstwa, mogą tam uczęszczać tylko w miarę wolnych miejsc.

Trzecia grupa, czyli sobotnie szkoły polonijne działają we Francji na zasadzie francuskiego prawa i na mocy ustawy z 1 lipca 1901 roku o stowarzyszeniach. Są powoływane właśnie przez stowarzyszenia, organizacje społeczne czy parafie katolickie i całkowicie odpowiedzialne za kształtowanie swojego grona pedagogicznego i realizowanie programu. Zazwyczaj w ramach programu realizują: język polski, historię i geografię oraz religię (Pugacewicz 2010).

Po 2008 roku, w okręgu paryskim oraz innych miastach Francji, powstały nowe społeczne szkoły polonijne we Francji. Ich ufundowanie zawdzięczamy inicjatywom liderek oraz wspólnot zaangażowanych w zaspokojenie dostępności do kontaktu i nauki języka polskiego dla dzieci i młodzieży. Szkoły te stały się także alternatywą dla polskich szkół narodowych działających przy ambasadzie lub szkolnych punktów konsultacyjnych. Nowe szkoły zjednoczyły się w Macierz Szkół Polonijnych we Francji (początek 2016 r.) i deklarują się stowarzyszeniem demokratycznych organizacji, 


\section{SM̂PP}

których nadrzędnym celem jest wspieranie nauczania języka polskiego, zarówno jako języka ojczystego, jak i języka obcego.

Na początku 2019 roku do Macierzy należało 11 szkół polonijnych, których koszty były w całości pokrywane przez rodziców dzieci tam uczęszczających. Do organizacji należały: szkoła „matka” inicjatorka macierzy Ecole Nova Polska (Paryż), Literka (St.-Germain-en-Laye), polska szkoła w Arcueil, polska szkoła w Bellerive sur Allier/Vichy, Kleks w Bordeaux, polska szkoła - filia ENP - w Orleanie, polska szkoła - Grenoble, Polinka w Tuluzie, polska szkoła w Aix en Provence, polska szkoła w Nicei oraz szkoła polska w Corbeil Essonnes. Każdego roku do wyżej wymienionych szkół uczęszcza około 750 uczniów, a uczy w nich 60 nauczycieli. W ramach programu odbywają się lekcje języka polskiego, geografii, historii Polski oraz elementy matematyki w ramach różnic programowych oraz religii jako przedmiotu dodatkowego.

Można wyróżnić trzy główne różnice w funkcjonowaniu "starych" i "nowych" sobotnich szkół polonijnych we Francji. Pierwsza, korzystają z lokali należących do ambasady, konsulatów, Polskiej Misji Katolickiej czy też innych organizacji polonijnych na terenie Francji. Druga zaś, funkcjonują bez żadnego stałego wsparcia ze strony rządu polskiego i rodzice sami opłacają koszty wynajmu lokali na wolnym rynku nieruchomości. Następną i zasadniczą różnicą jest fakt wynagradzania nauczycieli. Analogicznie, w pierwszym wypadku koszty ponosi RP, a w drugim - sami rodzice. Wielokrotne próby i prośby o systematyczne wsparcie ich działalności kierowane do rządów polskich nie przynoszą rezultatów. Pozostaje im przede wszystkim stawanie do różnych konkursów organizowanych przez stowarzyszenia, Ministerstwa Spraw Zagranicznych, Ministerstwo Edukacji czy Kancelarię Prezesa Rady Ministrów. Analizując najnowszą politykę wobec diaspor polskich stwierdzono:

iż w konsekwencji, z jednej strony, niską ocenę kondycji polskich organizacji imigranckich w krajach lub regionach będących celem wyjazdów powyżej wskazanych migrantów tłumaczono "charakterystyką" danej diaspory, a nie np. zbyt małą aktywnością instytucji państwa polskiego. Z drugiej zaś, brak w pewnych państwach lub regionach aktywnych organizacji, które występowałyby o środki w ramach procedur konkursowych typowych dla "nowej” polityki polonijnej, utrwalał ten stan. Można zatem mówić o występowaniu uwarunkowanego klasowo mechanizmu "błędnego koła”, który wykluczał pewne kategorie osób z tworzonej przez „nową" politykę polonijną transnarodowej przestrzeni relacji państwa polskiego z diasporą polską (Nowak i Nowosielski (2017: 84).

Nowe placówki zostały objęte "nową" polityką polonijną, co za tym idzie nie zdołały skorzystać ze środków państwowych przeznaczonych na wyposażenie sal w materiały dydaktyczne, nauczyciele zaś nie posiadają żadnych przywilejów pracowniczych w postaci pełnych i regularnych wynagrodzeń wraz ze składkami na ubezpieczenia społeczne, a przede wszystkim nie mają swoich stałych przestrzeni edukacyjnych. Z raportu nad stanem polskiego szkolnictwa w Wielkiej Brytanii płyną podobne wnioski, choć: 
zauważono, że nauczyciele nie dostają w nich o wiele wyższego wynagrodzenia, niż w szkołach społecznych; rodzice dopłacają, aby zachować nauczanie matematyki (wycofanej przez MEN z programu), czy innych zajęć dodatkowych i angażują się w życie szkoły itd. Zatem w istocie placówka taka niewiele różni się od szkoły społecznej, za wyjątkiem tego, że programy pomocy ze strony kraju trafiają do niej w pierwszej kolejności, na przykład fundusze na wynajem sal (Raport PAU 2011).

Badania przeprowadzone we Francji unaoczniają fakt, iż są szkoły we Francji, w których nauczyciele nie są wynagradzani, czyli pracują charytatywnie.

Trzecią różnicą, charakteryzującą omawiane szkoły jest znajomość języka polskiego wśród dzieci. W rozporządzeniu Ministra Edukacji Narodowej i Sportu z dnia 2 września 2004 r. w sprawie kształcenia dzieci obywateli polskich czasowo przebywających za granicą (DzU z 2004., Nr 194, poz. 1986) zakłada się stan idealny, który miałby charakteryzować ostatnią falę migracji. Ustawodawca nie przewiduje, iż najmłodsze dzieci polskiego pochodzenia urodziły się już poza granicami Polski. Zdecydowana większość z nich, nie potrafi w języku polskim sprawnie czytać ani pisać. Coraz częściej mają za jednego z rodziców osobę o innej tożsamości narodowej.

Według Iwony Pugacewicz historia zatoczyła koło i szkoła polonijna ponownie stała się niedostępna dla dzieci polskiego pochodzenia urodzonych we Francji. Dla tych dzieci język polski jest językiem drugim i nawet obcym. Aby zwiększyć powodzenie procesu ich nauczania, nauczyciele wykorzystują do komunikacji z nimi znajomość języka francuskiego (Pugacewicz 2010, 293).

\section{Kobiety od zadań specjalnych}

Kobiety wielokrotnie były organizatorkami powojennej oświaty polonijnej na całym świecie (Leoński, Wątróbski 2009), chociaż we Francji, jeszcze w okresie międzywojennym, organizatorami szkolnictwa polonijnego byli głównie mężczyźni (Ambrochowicz-Gajownik 2018: 212). Dzisiejszy stan rzeczy jest zdeterminowany przez nowe czynniki, między innymi fakt, iż ostatnią falę migracji tworzą zarówno pełne rodziny polskie, jak i emigracja młodych kobiet polskich, które z czasem zakładają już rodziny na emigracji. Nasilenie przepływów migracyjnych wraz z jej zwiększoną feminizacją (Warat 2008) przynoszą także wzrost badań podkreślających różnice w podejmowaniu i realizacji procesu migracji ze względu na płeć:

Rozpatrywanie płci migranta nie ma jedynie na celu ustalenia liczby migrujących kobiet i mężczyzn, lecz pozwala przede wszystkim zrozumieć, jak role i zadania przypisane do płci kulturowej wpływają na przebieg i skutki procesów migracyjnych, w tym mobilność, często związaną z przymusem opuszczenia na określony czas rodziny, oraz dostęp na rynku pracy, czyli do konkretnych sektorów czy zawodów (Kindler, Napierała 2010: 7). 


\section{SM̂PP}

Powodem wyjazdów są najczęściej względy ekonomiczne, ale coraz częściej motywacją są też edukacja, skuteczniejsza ścieżka kariery. Według Doroty Praszałowicz (2008: 52) podczas migracji postawa jednostki często się zmienia, wzrasta jej poczucie własnej wartości, dochodzą do głosu nowe ambicje. Migrant z osoby konserwatywnej staje się innowatorem. Badacze mówią wtedy o changing migration project. Z perspektywy gender studies jest interesujące, jak dalece migrujące kobiety wykazują postawy innowacyjne.

Podejmując się nowych zadań, wkraczając w nowe środowiska, konteksty społeczne i nawet polityczne wchodzą w role, które wymagają podejmowania określonych działań:

Należy właśnie pamiętać, że uczestniczki polskiej diaspory przejawiają swą aktywność w miejscach, gdzie często rola i pozycja kobiety są inaczej zdefiniowane niż w kulturze polskiej i w związku z tym może wystąpić sytuacja konfliktowa. Jest to dodatkowa trudność, jaką napotykają w swej działalności (Leoński, Wątróbski 2009: 13).

W przypadku Francji, Polki wchodzą we francuskie życie społeczne uwarunkowane polską wizją macierzyństwa, gdzie matki są obarczane całkowitą odpowiedzialnością za rozwój dziecka, jego zdrowie psychiczne i fizyczne (Budrowska 2000), a czego nie odnajdziemy w społeczeństwie francuskim (Badinter 1998).

Przyjęta przeze mnie perspektywa badań ma na celu nie tylko przeprowadzenie analizy na poziomie makro, czyli współczesnych uwarunkowań procesów migracyjnych, czy na poziomie mezo, gdzie w centrum uwagi znajduje się zorganizowana sieć społecznych szkół polonijnych, ale także na zdiagnozowaniu indywidualnych zasobów osób zaangażowanych w działalność polonijną. Pierwsze rezultaty, zebrane z około 70 ankiet, pochodzą w 95\% od Polek, a pozostałe 5\% zawiera odpowiedzi ojców zarówno polskich, jak i francuskich. W społecznych szkołach polonijnych są one założycielkami, równocześnie matkami oraz nauczycielkami, należą do dwóch przedziałów wiekowych 30-40 lat oraz 40-50 lat. W zdecydowanej większości (80\%) posiadają wyższe wykształcenie i pochodzą z polskich miast z liczbą mieszkańców powyżej 100 tys. Spędzony dotychczas czas na emigracji to w kolejności: powyżej 10 lat, następnie 3-5 lat oraz 5-10 lat. W ponad 90\% tworzą rodziny dwukulturowe. Uważają, że uczestnictwo w polskiej szkole weekendowej nie wystarczy do podtrzymania języka polskiego oraz więzi z Polską. I, tak samo jak nauczycielki, zauważają:

Język polski jest jednym z podstawowych narzędzi do utrzymania polskości. Natomiast te mamy oczekują, że my wszystkiego dzieci nauczymy. To jest niewyobrażalne w 4 godziny w tygodniu. (...) Wydaje mi się, że troszkę za mało czasu na te lekcje. Cały czas mi się wydaje, że największy wpływ ma rodzina. Szkoła może pomagać. (...) Są dzieci, które przychodzą do nas na zajęcia, a rodzice, którzy są Polakami lub jedno z rodziców, szczególnie mamy, często planowo od początku nie rozmawiają po polsku. <D1 >2

2 Na potrzeby pracy wywiady zostały zakodowane alfabetycznie według daty ich przeprowadzenia. 
Respondentki przyznają, że gdy tylko zauważą taką sytuację w szkole interweniują i starają się rozmawiać i wspierać rodzica.

Ja mogę powiedzieć o tym, co sama robię. Spędzać czas z dzieckiem, rozmawiać o życiu. O sytuacji w jakiej jesteśmy. Mieć dobry kontakt z dzieckiem. (...) Pewnie są jeszcze jakieś święta. Żeby dzieci wiedziały, że w Wigilię nie jemy owoców morza. <D1>

\section{Menadżerki od zadań niemożliwych}

Polska emigrantka, menadżerka zakłada stowarzyszenie (choć przyjeżdżając do Francji nie dysponuje dobrą znajomością języka francuskiego), korzysta z własnych zgromadzonych kapitałów społecznego i kulturowego, ale także kapitału ekonomicznego swojego francuskiego partnera. Jest zdeterminowana i ma poczucie sprawczości, które jest poddawane różnorakim próbom. Co roku nie ma pewności, ile nowych dzieci zasili działalność szkoły, czy umowa wynajmu lokalu - w którym zdążyli się zadomowić - zostanie przedłużona. Zestaw jej menadżerskich umiejętności musi zawierać kompetencje głównej księgowej oraz dyrektora do spraw zarządzania kadrami. Aby skorzystać z ewentualnego programu finansowania rządowego powinna wykazać się sprawnością w pisaniu wniosków grantowych, a następnie sprawdzić się jako kierowniczka wykonawcza projektu.

Tak, to jest taka sinusoida. Raz na dole, raz na górze. Czuję się sama w tym projekcie. Teraz borykam się z problemami kadrowymi (...). I ja teraz muszę się zająć administracją i nauczaniem. I taka się czuję od wszystkiego i do końca nie wiem, czy dobrze się wszystkim zajmuję. $<\mathrm{C} 1>$

Polska szkoła w Paryżu wynajmuje kilka sal po cenie rynkowej od francuskiej prywatnej szkoły podstawowej. Zaś w szkole na południu Francji, miasto udostępnia dwie sale do pracy za symboliczną opłatą. Obydwie placówki działają według francuskiego prawa o stowarzyszeniach i są finansowane w całości przez fundusze rodziców. Szkoła w Paryżu uiszczała w 2017 roku 2700 euro miesięcznie za dostępność kilku sal w wymiarze 32 godzin. Mniejsza szkoła na południu Francji za symboliczną kwotę kilkudziesięciu euro rocznie wynajmuje dwie sale w Maison de la Citoyenneté od władz miasta. Różnice między szkołami dotyczące bazy lokalowej są bardzo duże, zarówno na poziomie materialnym, jak i funkcjonalnym. Możliwości finansowe szkół wpływają na jakość ich pracy dydaktycznej, która już na samym wstępie wymaga lepszej samoorganizacji w czasie i przestrzeni. Kadra nauczycielska zdaje sobie sprawę z niegodności, które odczuwają dzieci.

Mamy bardzo duże problemy lokalowe i to się odbija na pracy codziennej, ponieważ niejednokrotnie mamy kilka grup klasowych w sali. Parawany niekoniecznie oddzielają jedną 
klasę od drugiej. (...) Dzieci nie potrafią się skupić np. na tym co jest w tej części sali, bo być może jest głośno za parawanem. <D1>

I dalej, według drugiej respondentki:

Idealnie byłoby mieć własny lokal. Bo ja cały czas powtarzam, gdy nie ma tej bazy, tej oazy, to nie ma rozwoju. Nie ma bańki, wokół której ludzie mogliby się jednoczyć. Mi by się marzyło, żeby rodzice mogli mieć taką bazę. Mieć swoją półkę w bibliotece, miejsce spotkań. $<$ C1 $>$

Mniejsza szkoła nie zapewnia w ogóle katechezy z udziałem polskich księży (nie było takiego zapotrzebowania ze strony rodziców).

Jesteśmy laicką szkołą, to jest założenie stowarzyszenia. To jest jeden z warunków, który przestrzegamy (...) Widać ten podział Polonii, że jesteśmy tą Polonią z (...) i jest jakaś inna Polonia z Kościoła. $<\mathrm{C} 1>$

Szkoła w Paryżu, z uwagi na nieprzyznanie katechety z ramienia Polskiej Misji Katolickiej, zdecydowała się samodzielnie znaleźć polską katechetkę i w ten sposób zapewnić zajęcia, które przygotują dzieci do przyjęcia sakramentów już w kościele na terenie dzielnicy (czyli francuskiego kościoła katolickiego), w której szkoła wynajmuje pomieszczenia.

Obie szkoły prowadzą swoje biblioteczki, kupują polskie nowości wydawnicze, przygotowują spektakle i spotkania o wysokiej jakości estetycznej i merytorycznej. Szkoła w Paryżu współpracuje z Polską Biblioteką w Paryżu, gdzie każdego środowego przedpołudnia młodsze dzieci mają zapewnione interesujące zajęcia. Dzięki swoim umiejętnościom menadżerskimi, wykorzystaniu kapitałów społecznych i ekonomicznych, własnych wpływów i zasobów (czasami nawet materialnych) środowisko to podjęło się i zapisało w swoim statucie takie działania jak: rozwijanie i promowanie inicjatyw sprzyjających nauczaniu języka polskiego jako ojczystego i obcego, propagowanie kultury polskiej we Francji oraz współpracę i koordynację polonijnych organizacji oświatowych (stowarzyszeń, szkół społecznych) na terenie Francji.

Liderki zadeklarowały rozwijanie współpracy organizacji stowarzyszonych w Macierzy z władzami oświatowymi Polski, w szczególności w zakresie konsultacji projektów oświatowych związanych z oświatą polską realizowaną poza granicami Rzeczpospolitej Polskiej. Działają na rzecz wzrostu świadomości znaczenia wielojęzyczności oraz inicjowania szkoleń metodycznych dla nauczycieli na terenie Francji przy współpracy z oświatowymi władzami polskimi. Podejmują działania na rzecz zrównania szans nauczycieli i uczniów polonijnych przebywających na terenie Francji. Oferują wszechstronną pomoc wszystkim podmiotom zaangażowanym w tworzenie i prowadzenie szkół. 


\section{Przewodniczki}

Aby proces zachowania kontaktów z państwem wysyłającym był możliwy do zrealizowania, musi zaistnieć relacja emocjonalna, zwłaszcza u dzieci emigrantów urodzonych już poza granicami ojczyzny rodziców z krajem pochodzenia rodziców. Relacja ta jest składową tożsamości narodowej, a której zachowanie może być trudne w obliczu opartej na wartościach republikańskich kultury francuskiej. Z jednej strony, nowi obywatele są motywowani do udziału w życiu politycznym wspólnoty francuskiej, z drugiej zaś ten:

model inkluzji politycznej w duchu francuskim wywodzi się z idei indywidualizmu oraz kulturowej asymilacji. Opiera się na koncepcji, która głosi, że zintegrowana jednostka staje się integralną częścią społeczeństwa francuskiego, a tym samym przestaje być postrzegana jako element innej grupy czy wspólnoty (Lesińska 2013: 143).

Republikański model integracji jest niezrozumiały, jeśli nie zostanie przywołana koncepcja państwa narodowego (Noiriel 2010), z której wynika tamtejszy model inkluzji imigrantów. W stosunku do nich opiera się on na przekonaniu, że emigranci są w stanie i powinni zintegrować się w ramach politycznej wspólnoty, w której nie ma miejsca na długotrwałą kulturową czy etniczną odrębność (Lesińska 2013). U podstaw modelu republikańskiego leży wiara w efektywny wpływ socjalizacji, przede wszystkim w laickiej i republikańskiej szkole, gdzie jednostka powinna zinternalizować odpowiednie kody zachowań oraz wartości, takie jak wolność, równość i braterstwo.

Szkoła we Francji zaczyna się ok. godz. 8-8.30 i trwa dla młodszych do 16-16.30, a dla starszych dzieci nawet do godziny 18.00. Po tak obciążonym tygodniu, dzieci przyjeżdżają w soboty do szkół polskich rano, na godzinę 9.00, aby uczestniczyć w zajęciach do godziny 13.00. Przyjeżdżają zarówno do miasta na południu Francji, jak i do Paryża z miejscowości odległych o kilkadziesiąt kilometrów, są przypadki, że aż o 100 kilometrów.

Dzieci w szkole w Paryżu uczą się języka polskiego we francuskiej scenerii klasowej (gazetki, słówka, odmiany czasowników), ponieważ nie mogą na stałe niczego tam zostawiać ani wieszać. Są podzielone na grupy nie tylko ze względu na wiek, ale także ze względu na znajomość języka. Wśród nich są też dzieci, wobec których stosuje się naukę języka polskiego jako języka drugiego, obcego. Starsze grupy czytają, piszą, uczą się gramatyki. Uczą się geografii i historii polski oraz literatury polskiej. Najmłodsze grupy odpowiednio do ich wieku uczy się przez zabawę, śpiew, rytmikę oraz odczytywanie bajek przez nauczyciela:

To wyszło od małych dzieci. Dzieci, które dojeżdżają do nas na zajęcia na 4 godziny. Dzieci, które mają 3 latka, to wiadomo, że one potrzebują muzyki, zajęć rytmicznych, teatr. To są zajęcia bardzo przyjemne, ale i także bardzo skuteczne. (...) czyli wychowanie poprzez sztukę, bo wiadomo, że od tych wrażeń pozytywnych zaczyna się miłość do języka. <A1> 
Druga placówka, przyjęła podobną strategię i dyrektorka deklaruje, że:

nie chcemy być tacy szkolno-szkolni. To ma być przyjemne. To ma się kojarzyć w miarę przyjemnie. Na ile się da. $<\mathrm{C} 1>$

Obie placówki zmagają się z każdorazowym przygotowaniem zajęć, które zaczynają się od wynoszenia rzeczy z malutkiego magazynu bądź szaf, w których wolno im przechowywać rzeczy szkoły polskiej. Przewodniczki wspierają dzieci od samego rana, próbują zainteresować, zmotywować i przekazać kolejną porcję wiedzy, choć zdają sobie sprawę, iż dzieci i młodzież są zmęczeni:

Obudzenie ciekawości u dzieci. Chciałabym, żeby dzieci pokochały książki i zaczęły się nimi interesować. (...) Gorzej z kontaktem ze sztuką i ja chciałabym, żeby potraktować tę książkę jako pierwszą galerię sztuki, do której one wejdą. <D1>

Kadra próbuje wieloma nowatorskimi pomysłami uzmysłowić rodzicom i dzieciom zalety podwójnej tożsamości nieobarczonej konfliktem, a umiejętnie czerpiącej z obu kultur i zasobów przez nie przekazywanych. Wspierają rodziców swoim doświadczeniem pedagogicznym w sytuacjach kryzysowych zaistniałych w szkołach francuskich, organizują wsparcie logopedyczne i psychologiczne. Współpracują z Uniwersytetem Jagiellońskim w dziedzinie nauczania dwujęzycznego, dzięki czemu same dokształcają się z metod odpowiednich do takiego typu nauczania. Edukują nie tylko dzieci, także rodziców wprowadzają w zagadnienie dwujęzyczności i wyzwania z tym związane. Organizują spotkania opiekunów ze specjalistami z tego zakresu i konsekwentnie podejmują się wspierania idei nauczania dwujęzycznego.

Mieliśmy konferencję o dwujęzyczności. Akurat rodzice naszych dzieci mają świadomość jak dwujęzyczność jest ważna. Uczestniczyłam w tej konferencji i słyszałam, że bardzo się tym interesują. $<D 1>$

Bycie przewodniczką jest niekończącą się misją. Nieustanne poszukują nowych materiałów edukacyjnych, nowych publikacji, najciekawszych piosenek czy wierszy, które mogłyby zainteresować ich podopiecznych. Łączą sferę języka ze sztukami plastycznymi, z muzyką i teatrem dla dzieci. Szkoły pod ich przewodnictwem stają się domami kultury polskiej, klubami dyskusyjnymi i miejscem spotkań najnowszej Polonii, nie tylko z okazji Świąt Bożego Narodzenia i Wielkanocy.

\section{Obywatelki świata}

Kobiety, które określiłam jako obywatelki świata, często ukończyły ostatni etap edukacji we Francji i pracują w środowisku wyłącznie francuskim lub międzynarodowym. Poruszają się swobodnie w obydwu lub więcej kulturach. Obywatelki świata, żyjąc 
w wielokulturowym społeczeństwie, same współtworzą także takie rodziny. Ich dzieci spędzają większość czasu w środowisku wyłącznie francuskim, zakładającym jak najszybszą integrację i asymilację. Nie mają możliwości i szans, aby rozwijać swoje kompetencje językowe w drugim języku na równi z językiem francuskim.

Na początku roku szkolnego, kiedy część dzieci, które przyszły do szkoły były bardzo zestresowane i bardzo zamknięte. Ja mówię o mniejszych dzieciach między 3-5 rokiem. Teraz już wiem, że rozumiały język polski, ale nie chciały się odezwać w jakimkolwiek języku. I naprawdę moje zajęcia z książkami pomagały się otworzyć tym dzieciom. <D1>

Sytuacja może być poważniejsza i czasami nieodwracalna, gdy to matka dziecka jest Francuzką a ojciec Polakiem. Przeprowadzone przez Romana Laskowskiego w Szwecji badania na grupie dzieci polskiego pochodzenia, potwierdzają wyżej poczynione obserwacje. Zaobserwowano, że to matka ma decydujący wpływ na język dziecka oraz prawidłowość, iż drugie pokolenie imigrantów preferuje (także w rozmowach rodzeństwa) język dominujący, język kraju zamieszkania (Laskowski 2015: 61).

Do sukcesów szkół można zaliczyć „odzyskiwanie” tożsamości dzieci (np. z zaległościami w języku polskim). Badaczka miała możliwość obserwacji pracy z dziećmi, które zapisano do polonijnej szkoły w przedziale wiekowym 8-10 lat w celu nauczenia języka polskiego, dzieci rozumiały język polski, ale nie mówiły.

Potrafiliśmy znaleźć rozwiązanie dla tych dzieci słabo mówiących. I to jest największa sztuka dla tych dzieci słabo mówiących. Np. pan nauczyciel przygotowuje blok historyczny, po czym 2 panie nauczycielki są obecne na takiej lekcji łączonej 3 klas. I późnej te panie jeszcze raz ten materiał przerabiają od strony języka polskiego. To jest ogromna praca. Ale naprawdę są efekty. <A1>

Powstanie sobotnich szkół polonijnych, to nie tylko kwestia umiejętności menadżerskich organizatorek, to także silne poczucie własnej wartości, sprawczości i nieustanny samorozwój. Nie istnieje jeden podręcznik, który byłby wystarczający do nauczania dzieci uczęszczających do tego rodzaju szkół. A sam początek był lekcją dla nich samych.

Sami sobie jakoś radzimy. Szukamy. Sami tworzymy. Żaden podręcznik nie jest zaadaptowany do tak różnych poziomów języków, jak i grup wiekowych. <C1>

Później bardzo nam było trudno zgromadzić materiał pedagogiczny, podręczniki. To było trochę takie poszukiwanie. Nie mieliśmy schematów. I to było najtrudniejsze (...) Program tworzył się w trakcie. Zaczęliśmy pracować w klasach wczesnoszkolnych z „Wesołą szkołą”, która zupełnie się nie sprawdziła. „Wesoła szkoła”, z którą pracowały dzieci w szkołach przykonsularnych. $<\mathrm{A} 1>$

W miarę upływu czasu i wypracowywania nowego sposobu pracy, stają się eks134 pertami i praktykami. 


\section{SM̂PP}

Zaczęliśmy spisywać swoją metodykę, pracę na polskich tekstach literackich, najłatwiejszych i najciekawszych dla dzieci. $<\mathrm{A} 1>$

Nieustannie obserwują dzieci, oczekiwania rodziców i starają się opracowywać modele możliwe do zaakceptowania przez nich.

Ale widzimy, jakie są realia. Jeżeli dziecko zaczyna do nas przychodzić, jak ma 3 lata, to maksymalnie daje się go zatrzymać przez 7 lat. Staram się odchodzić od tego nauczania „kto ty jesteś" i przebierania za Krakowiaków. (...) Chce, żeby to było nowoczesne nauczanie i dostosowane do nich i w tej rzeczywistości, w której oni żyją. Zawsze się odnoszę do ich rzeczywistości we Francji, bo tutaj żyją. Tu się urodzili i tutaj pewnie pozostaną, większość z nich. To jest ich miejsce na Ziemi. <C1>

Obywatelki świata zdają sobie sprawę, że ich możliwości są ograniczone czasem oraz obowiązkami dzieci wynikającymi ze szkoły francuskiej. Dzieci dorastają, program szkoły francuskiej staje się coraz bardziej czasochłonny, a one same mają potrzebę spędzania resztek wolnego czasu ze swoimi rówieśnikami z najbliższego kręgu. Nie narzucają sobie wychowania dzieci na twardych patriotów, raczej mają nadzieję, iż kiedyś dzieci same poczują potrzebę poszukiwania swoich kulturowych korzeni.

\section{Wnioski}

Utworzenie typologii, próba sklasyfikowania tych ról, może być potraktowana jako zabieg czysto formalny. Na co dzień przedstawione przez autorkę liderki, działając pod presją, łączą w sobie i w swoich działaniach wszystkie cechy oraz charakterystyki niezbędne do podjęcia wyzwań, z jakimi się zmagają. Zebrane dane dotyczą dużo szerszego tematu badawczego i zakresu obserwacji, wiele zacytowanych wypowiedzi mogłaby się stać inspiracją do opracowania kolejnych tematów, związanych z aktualnymi przeobrażeniami polonijnego szkolnictwa. Mimo że badania są przeprowadzane we Francji, autorka była wielokrotnie informowana o podobnych uwarunkowaniach szkolnictwa polonijnego w innych krajach Europy Zachodniej. Osoby, które zgłosiły się albo zgodziły na wywiad, to osoby zaangażowane nie tylko w swój własny zakres obowiązków w szkole, ale także w jej współtworzenie.

Zdefiniowanie działań kobiet zaangażowanych w stworzenie i funkcjonowanie społecznych szkół polonijnych miało na celu unaocznienie skali problemu, z jakim się zmagają. Ich placówki pełnią funkcję integrującą środowisko polonijne zainteresowane tego rodzaju nauczaniem. Zindywidualizowanym, wysoko wyspecjalizowanym, z nauczaniem języka polskiego jako drugiego i obcego. Placówki pełnią też rolę poradni pedagogiczno-psychologicznych, zatrudniając logopedów, w poważnych przypadkach kierując do polskich psychologów w Paryżu. Mogą pochwalić się realnymi efektami nauczania. Uruchamiając i wykorzystując drzemiące w nich potencjały, 
pozostają w poczuciu osamotnienia, bezsilności i wykluczenia. Walczą o stałe miejsce swoich placówek i stworzenie im polskiej przestrzeni:

Czujemy wypalenie. Działamy 10 lat. Brakuje nam „świeżej krwi”. <C1>

Początkowy okres działalności tych placówek obejmuje lata 2008-2009, natomiast oficjalne otwarcie francuskiego rynku pracy dla Polaków nastąpiło od 1 lipca roku 2008. Wcześniej Francja sukcesywnie otwierała możliwości legalnego zatrudnienia polskich pracowników w zależności od sektora. W tamtym okresie na francuski rynek pracy weszły kolejne osoby, które ukończyły we Francji studia, do nich dołączyli pracownicy międzynarodowych firm oraz instytucji unijnych. Nie znajdując odpowiednich dla siebie rozwiązań w dziedzinie edukacji, najmłodsza Polonia stosunkowo szybko zorganizowała się w tej kwestii. Często motywacją była po prostu chęć stworzenia przyjaznego miejsca dla swoich własnych dzieci. Po 10 latach niektórzy czują się już po prostu zmęczeni, a inni są świadkami odchodzenia od placówek własnych dzieci, wkraczających w nastoletni wiek.

Ich zaangażowanie i działalność nie przypominają charakterem paniki w obliczu otaczającej je wielokulturowości, są raczej świadomą próbą zatrzymania polskiego pierwiastka i wpisania go na trwałę w życiorysy dzieci. Badaczka odnajduje także ich charakterystykę, w określonej jako jedna z trzech strategii edukacyjnych polskich matek migrantek w Wielkiej Brytanii, pod terminem New Migrant Motherhood (Pustułka 2016). Prawdopodobnie rzadko mają okazję do autorefleksji, aby zdać sobie sprawę z procesów, jakie uruchomiła w nich ich własna migracja. A przecież nieustannie rozbudowują swoje kapitały i tworzą nowe sieci, zarówno wśród polskich migrantów, ale także pomiędzy polskimi i francuskimi środowiskami. Oswajają rzeczywistość, w której się znalazły, uczą się od siebie nawzajem. Ich działalność jest także potrzebą zaspokojenia ich własnych kontaktów z krajem pochodzenia. Zwłaszcza gdy powodem ich wyjazdu z kraju była „migracja serc” lub gdy bezpośrednim powodem osiedlenia się na stałe we Francji była więź emocjonalna. Obserwacje uczestniczące badaczki oraz wywiady dokumentują ich poczucie misji do spełnienia, w wymiarze indywidualnym (rodzina) i kolektywnym (dla innych rodzin i ich dzieci). Rozpoczynając, kontynuując ścieżkę nauczycielską zaczynają się dokształcać, specjalizować w zagadnieniach związanych z dwujęzycznością, a przez to czują się bardziej dowartościowane w obszarze pracy zawodowej. Nawiązując współpracę z polskimi urzędami, nawołując do wsparcia, wkraczają na drogę działań o charakterze politycznym.

Z dotychczas przeprowadzonych badań wynika, iż kierują się określonym wzorcem przekazywania dziedzictwa narodowego Polski oraz języka polskiego jako nośnika polskiej tożsamości narodowej. Tak jak dla Antoniny Kłoskowskiej (2005) kultura narodowa była częścią uniwersum kulturowego, ukonstytuowanego z takich systemów symbolicznych jak język, sztuka i literatura, wiedza i nauka, religia i obyczaje, 136 tak i dla nich stała się ona narzędziem do tworzenia wspólnoty ponadnarodowej. 


\section{SM̂PP}

\section{Bibliografia}

Ambrochowicz-Gajownik A. (2018), Szkolnictwo polonijne w południowo-wschodniej Francji z perspektywy konsulatu polskiego w Marsylii w okresie międzywojennym, "Res Gestae. Czasopismo historyczne" nr 6, s. 197-215.

Badinter B. (1998), Historia miłości macierzyńskiej, przeł. K. Choiński, Warszawa: Oficyna Wydawnicza Volumen.

Diaz D. (2014), Un asile pour tous les peuples? Exilés et réfugiés étrangers en France au cours du premier XIXe siècle, Paris: Armand Colin.

Dzwonkowski R. (1981), Szkolnictwo polskie we Francji w czasie I/ wojny światowej (1939-1945), "Studia Polonijne", t. 4, s. 187-199.

Dzwonkowski R. (1983), Szkolnictwo polonijne we Francji po // wojnie światowej, „Studia Polonijne" t. 7, 183-205.

Giddens A. (2001), Nowoczesność i Tożsamość. „Ja” i społeczeństwo w epoce późnej nowoczesności, przeł. A. Szulżycka, Warszawa: PWN.

Główny Urząd Statystyczny https://stat.gov.pl/obszary-tematyczne/ludnosc/migracje-zagraniczne-ludnosci/informacja-o-rozmiarach-i-kierunkach-czasowej-emigracji-z-polski-wlatach-2004-2017,2,11.html [dostęp: 22.03.2019].

Grzymała-Moszczyńska H, Grzymała-Moszczyńska J., Durlik-Marcinkowska J., Szydłowska P. (2015), (Nie)łatwe powroty do domu? Funkcjonowanie dzieci i młodzieży powracających z emigracji, Warszawa: Fundacja Centrum im. prof. Bronisława Geremka.

Kaczmarczyk P., Okólski M. (2005), Migracje specjalistów wysokiej klasy w kontekście członkostwa Polski w Unii Europejskiej, Warszawa: OBM.

Kindler M., Napierała J. (2010), Migracje kobiet, przypadek Polski, Warszawa: Scholar.

Laskowski R. (2015), Bilingwizm w drugiej generacji emigrantów, „Zeszyty Naukowe”, seria trzecia, nr 3, s. 49-57.

Kłoskowska A. (2005). Kultury narodowe u korzeni, Warszawa: Wydawnictwo PWN.

Leoński J., Wątróbski L. (2018), Socjologiczne, kulturowe, językowe i historyczne szkice o diasporze polskiej, Łódź: Wyższe Seminarium Duchowne w Łodzi/Archidiecezjalne Wydawnictwo Łódzkie.

Leoński J., Wątróbski L. (2009), Diaspora tom III, Diaspora kobiet polskich, Szczecin: Uniwersytet Szczeciński.

Lesińska M. (2013), Inkluzja polityczna imigrantów we współczesnej Europie, Warszawa: Scholar.

Lesińska M. Okólski M., Slany K., Solga B. (2014), Dekada członkostwa Polski w UE. Społeczne skutki emigracji Polaków po 2004 roku, Warszawa: Wydawnictwo Uniwersytetu Warszawskiego.

Małek A., Warat M. (red.), (2010), Ponad granicami. Kobiety, Migracje, Obywatelstwo, Kraków: Wydawnictwo UJ.

MSZ, Rządowy program współpracy z Polonią i Polakami za granicą w latach 2015-2020, https://www.msz.gov.pl/resource/70a7021e-304c-4075-a812-18e5b3410966:JCR [dostęp: 31.07.19]

Nowosielski M., Nowak, W. (2017), Nowa polityka polonijna" - obszar tworzenia wspólnoty czy przestrzeń gry interesów?, "Studia i Dyskusje” nr 37(2), s. 73-89.

Nisiobęcka A. (2018), Z Lens do Wałbrzycha, Warszawa: IPN.

Noiriel G. (2010), Une histoire du modèle français d'immigration, „Regards croisés sur l'économie", nr 8, s. 32-38. 
ORPEG, http://www.paryz.orpeg.pl/?q=historia_szkoly [dostęp: 25.07.2019].

PAU, http://pau.krakow.pl/index.php/en/dzialalnosc/inicjatywy-uchwaly-i-postulaty/archiwum/ nowa-polska-diaspora-2010 [dostęp: 25.03.2019].

Ponty J. (2008), Les Polonais en France de Louis XIV à nos jours, Paris, Paryż: Editions du Rocher.

Praszałowicz D. (2008), Polskie studia na temat migracji kobiet: wybrane perspektywy teoretyczne i wyniki badań, w: Slany K. (red.) Migracje kobiet, Kraków: Wydawnictwo Uniwersytetu Jagiellońskiego.

Pugacewicz I.H. (2010), Stan, perspektywy i problemy szkolnictwa z polskim językiem nauczania we Francji, w: Lewowicki, T., Nikitorowicz, J., Szczurek-Boruty A., Szkolnictwo z polskim językiem nauczania w państwach europejskich - stan, problemy i perspektywy, Białystok-Cieszyn-Warszawa: Uniwersytet w Białymstoku.

Pugacewicz, I.H. (2017), Batignolles 1842-1874. Edukacja Wielkiej Emigracji, Warszawa: ASPRA. Pustułka P., (2016), Transnational Educational Strategies of Polish Migrant Mothers Parenting in Great Britain, „Studia Migracyjne - Przegląd Polonijny”, z. 2 (160), s. 157-176.

Raport PAU, http://pau.krakow.pl/projekty_badawcze/raporty/Polskie_szkolnictwo_UK/Polskie _szkolnictwo_UK_RAPORT.pdf [dostęp: 18.08.19].

Raport INSEE, Les immigrés récemment arrivés en France, (2013), https://www.insee.fr/fr/statistiques/1281393 [dostęp: 19.09.19]

Slany K., Solga (koord.), (2014), Społeczne skutki poakcesyjnych migracji ludności Polski, Warszawa: Raport Komitetu Badań nad Migracjami Polskiej Akademii Nauk.

Warat E. (2008), Etniczność i gender - między teorią a praktyką, w: Slany K. (red.), Migracje kobiet, Kraków: Wydawnictwo Uniwersytetu Jagiellońskiego. 